DOI 10.37882/2223-2982.2021.03.34

\title{
АКТУАЛИЗАЦИЯ ЭТНОКУЛЬТУРНОГО НАСЛЕДИЯ В ПРОЦЕССЕ МОДЕРНИЗАЦИИ КОНФЕССИОНАЛЬНОЙ ИДЕНТИЧНОСТИ СЕЛЬСКОГО НАСЕЛЕНИЯ ТАТАРСТАНА ${ }^{1}$
}

\section{THE MAINSTREAMING \\ OF ETHNOCULTURAL HERITAGE \\ IN THE MODERNIZATION \\ OF CONFESSIONAL IDENTITY \\ OF RURAL POPULATION OF TATARSTAN}

A. Fazliev

A. Sattarova

Summary: During the transition period, in the context of a departure from the ideological paradigms of the recent past and the forced devaluation of established values, they led to a certain marginalization of culture, a loss of guidance on the way to spiritual origins, and the negative influence of non-traditional religious and confessional elements in Russia. Cultural traditions, which are socio-cultural heritage, in this respect form the "collective memory» of society, ensure continuity and stability of its development. Defining guidelines for a national policy of the Russian state has served as a centuries-old cultural values and traditions of people, their gender demographic groups, studying the role which regional rural settlements shows potential for preserving cultural identity and providing the Russian spiritual unity.

Keywords: ethnic culture, rural environment, heritage, Muslim Tatars, domestic Islamic traditions.

\author{
Фазлиев Айваз Миннегосманович \\ К.и.н., дочент, Казанский (Приволжский) \\ федеральный университет \\ aivazik@mail.ru \\ Саттарова Аделя Ильхамовна \\ К.и.н., доцент, Казанский (Приволжский) \\ федеральный университет \\ satadel@inbox.ru
}

Аннотация: Активный поиск ответов в переходный период в условиях отхода от идеологических парадигм недавнего прошлого и форсированной девальвации устоявшихся ценностей привели к известной маргинализации культуры, потере ориентиров на пути к духовным истокам, негативному влиянию нетрадиционных для России религиозно-конфессиональных элементов. Культурные традиции, являющиеся социокультурным наследием, в данном отношении формируют «коллективную память» общества, обеспечивают преемственность и устойчивость его развития. Определяющими ориентирами национальной политики российского государства служат многовековые культурные ценности и традиции народов, их гендерно-демографических групп, изучение роли которых на примере региональных сельских поселений показывает потенциал сохранения культурной идентичности и обеспечения российского духовного единства.

Ключевые слова: этнокультура, сельская среда, наследие, татары-мусульмане, «народно-исламские» традиции.

достоянием того или иного этноса.

В научной литературе дается следующее определение термина «этнокультура»: «этнокультура - это совокупность традиционных ценностей, отношений и поведенческих особенностей, воплощенных в материальной, духовной, социальной жизнедеятельности этноса, сложившихся в прошлом, развивающихся в исторической социодинамике и постоянно обогащающих этнической спецификой культуру в различных формах самореализации людей» [2]. Этнокультура выступает в качестве системы взаимодействия этих составляющих, играет важную роль в процессах глобализации, поскольку, как было сказано, в современном мире идет активная ассимиляция этносов, унификация культуры, происходит исчезновение и изменение этнокультурных особенностей, ми этнической культуры, которые являются культурным 
а уровень национального самосознания претерпевает существенные изменения. Например, татарское национальное самосознание, которое как цельное общественное явление сформировалось в конце XIX века, играет большую роль в этнокультурных процессах современного татарстанского общества, оказывая влияние на социокультурный его облик. Именно этнокультура является бесценным источником материальных и духовно-нравственных ценностей народа. В современных условиях российское общество, освобождаясь от прежних конструкций коммунистическо-идеологической системы, возвращает в реальную жизнь проверенные историей исконные традиции и ценности.

В наши дни мусульманские традиции продолжают активно возвращаться в общественно-политическую и духовную жизнь татарского общества. Современные исследователи ментальности сельского населения отмечают о наличии различных форм проявления религиозности и конфессиональной идентичности в татарском социуме, которые были вызваны политико-правовыми, социально-экономическими и этнокультурными переменами в конфессиональной идеологии российского общества, что инициировало инверсию духовных ценностей и возрождение религиозных институтов, открытие культовых и образовательных учреждений, массовое издание религиозной литературы. Этот процесс как по формам поиска духовно-религиозных ценностей, так и по выбору способов и методологии реализации религиозных потребностей имеет сложный и неоднозначный характер. К началу XXI в. в связи со структурно-организационным возрождением духовных институтов на селе в общих чертах обозначились ориентиры развития духовных и идейно-целевых начал для формирования новой конфессиональной идентичности. К сожалению, ее мировоззренческие основы имели двойственный характер и лежали между ценностями средневекового традиционного и мультикультурными реалиями постиндустриального обществ.

Безусловно, такая неопределенность была связана не столько с личным выбором сельских мусульманских сообществ, сколько стечением ряда объективных обстоятельств. В этом немаловажную роль сыграли крушение основ прежней социокультуры, неустроенность в жизни и отчаяние, которые толкали селян к религии, поскольку они испытывали сильную потребность в духовной мотивации жизненных ценностей и социально-правовых норм новых форм общественных порядков. Религиозная потребность для многих из них сохраняла значение особого базисного стержня в духовной и бытовой жизни, выступая неотъемлемым элементом семейно-бытовой повседневности и основой для нравственного и духовного воспитания подрастающего поколения. Многие сельские жители, как правило, на бессознательном уровне воспринимали религиозность как естественное проявление общественной жизни, как особую форму «деревенской культуры» и этнокультурного выживания татарского этноса.

В процессе многовековой эволюции мусульманских религиозных институтов в татарской деревне сформировались особые «народно-исламские» традиции, которые были духовным стержнем национального крестьянства, пронизывающим почти все стороны его жизнедеятельности. Они отражались не только в моральнонравственных и социально-правовых устоях сельских социумов, но и в интерьерах крестьянских жилищ, одежде и еде (халяльная, нехаляльная). В этом, конечно, определяющую роль играла поземельная община, как традиционная форма крестьянского бытия, которая сформировала особые народные (земледельческие) и религиозные (морально-нравственные) традиции локальных сельских общностей. Вся эта система локальных ценностей строилась не только на принципах ограничения контактов за пределами джиенных округов или крестьянской поземельной общины, но и на всеохватывающем контроле «мира» над своими членами. Контролирующая функция поземельной общины находила свое отражение как в жестких требованиях к производственной деятельности, так и в исполнении местных форм мусульманского богослужения и обрядов. Крестьянская поземельная община была не только хранительницей хозяйственных устоев, обычаев и традиций в татарской деревне или джиенном округе, но и строгим цербером моральных и нравственных устоев селян. Община поощряла крестьян, которые отличались религиозностью и щедрой благотворительностью на религиозные и социальные потребности деревни, и, напротив, осуждала скупых, инертных, неграмотных, нарушителей исламских норм поведения. В татарской деревне нравственно-этические нормы поведения жителей, формы проведения различных видов взаимопомощи (помочей) и культурного досуга, как правило, напрямую связывались с основными идейными ценностями мусульманского вероучения. Все это способствовало формированию особой сельской конфессиональной идентичности. Причем отдельные элементы официального (ортодоксального) мусульманского вероучения во многих татарских деревнях воспринимались с некоторой поправкой на местные традиции и повседневность, сохраняя характерные элементы сельского своеобразия.

Устойчивая конфессиональная идентичность населения татарской деревни до начала XX в. сохранилась не столько из-за локального характера развития крестьянского житейского сознания, сколько из-за натуральности сельского производства. После интенсивной индустриализации городских и сельских производств - старые (патриархальные) формы организации хозяйственной жизни в деревне, выстроенные на основе экономики полунатурального хозяйства и многовековых 
народно-исламских традиций, стали неэффективными. В ходе индустриально-урбанизационных перемен в России несмотря на то, что определяющим в духовной и материальной повседневности татарского общества попрежнему оставался ислам, патриархальные родовые и семейно-брачные основы крестьянского быта, морально-нравственные устои сельских общин испытали внешнее социокультурное влияние.

Известно, что ислам, который исповедовал татарский народ, в течение многих веков выполнял особые этно-охранительные функции. Еще в период имперской России специфическое отношение властей к мусульманским народам поставило их в особые социально-религиозные и этнокультурные условия, когда при наличии официальной государственной религии - православия, повседневный уклад татар и других неправославных этносов определялся устоями собственных религиозных традиций. Главной особенностью этой державной политики было и то, что в Российской империи мусульманам, в том числе татарам, было запрещено открывать светские учебные и культурно-просветительские заведения; обучение на родном языке могло быть только религиозным. Царское правительство, как правило, не вмешивалось в процесс реализации мусульманского богослужения и образования, поскольку оно его не финансировало и не считало себя ответственным за это. После установления Советской власти на территории Российской империи и провозглашения ее интернациональным содружеством наций и народностей большевистское руководство на долгие десятилетия определило свое отношение к религиозным объединениям, что в первое время верующим татарским населением воспринималось как гарант восстановления социальной справедливости в плане свободного исповедания религий. Однако с укреплением советских органов власти на местах в татарской деревне, как и в других этнических сельских населенных пунктах, параллельно происходило ограничение прав религиозных институтов и верующих. В советский период бытовые традиции татарского крестьянства, выстроенные с учетом религиозной специфики и этнической идентичности локальных сельских общин, а также семейных отношений, связанных с обрядовой стороной ислама, сильно видоизменились. В условиях воинствующего атеизма мусульманское вероучение постепенно ограничилось сферой локальных семейно-бытовых обычаев и обрядов. Таким образом, грубое вмешательство властей во внутренний социальный и духовный уклад татарской деревни, нетерпимость к мусульманскому вероучению и многовековым традициям стали причиной насильственного разрыва в народно-религиозной эволюции крестьянства. К тому же глубокое проникновение советской атеистической идеологии во все сферы жизни татарского народа свело роль традиционных духовных институтов к минимуму. Однако, несмотря на все эти социальные и политические перипетии, мусуль- манское вероучение долгие годы оставалось ключевым фактором, позволявшим татарам сохраняться как этносу и сопротивляться тем переменам, которые несли угрозу их традиционному этнокультурному существованию и конфессиональной идентичности.

Современное (постсоветское) состояние религиозности татарского сельского социума и религиозного сознания мусульманского духовенства опирается в основном на принципы восстановления утерянных конфессиональных позиций. Одно из проявлений роста религиозности видится в том, что в течение постсоветского периода в разных районах республики и селах Татарстана было образовано более 1500 мусульманских религиозных объединений, возведено более 2 тыс. мечетей (почти на каждую татарскую деревню по мечети), открыто несколько десятков мусульманских образовательных учреждений. По нашим подсчетам, молодёжь и люди среднего возраста, подражая старшему поколению, начали посещать сельские мечети в дни мусульманских праздников (50\% и более), пятничные молитвы (до 20\%) и соблюдать посты (30\% и более). Но, к сожалению, большинство из них рационалисты («формально или пассивно верующие»), если и придерживаются религиозных традиций, то из уважения к старшим или исходя из других житейских обстоятельств, а не по убеждению [3]. «Формально верующие» более склонны к показной вере, чем к открытому неверию, они всячески избегают «крикливого» безбожия, как правило, стесняются излить душу, боясь уронить свой авторитет среди селян. В связи с этим значительная часть из них совершают религиозную обрядность и благотворительность по соображениям общественного порядка и морально-нравственной комфортности. Поведение этой группы селян наглядно показывает, что религиозные традиции в повседневной жизни деревни сильны и осуждение окружающих в безбожии для них значимо. Это позволяет нам сделать заключение, что группа «пассивно верующих» селян состояла в основном из верующих мужчин, возможно, с сомнениями, вызванными светскими обстоятельствами, но они должны были пройти проверку временем. Возможно, что мужчины в силу своих психологических особенностей верили в бога в латентной форме. Религиозность была не только среди рядовых сельских жителей, но и среди бывших партийно-советских работников, многие из которых посчитали своим долгом стать священнослужителями, у некоторых из них в роду (деды, прадеды и др.) были священнослужителями.

Однако, несмотря на это, в настоящее время среди приверженцев мусульманской веры ярко прослеживается процесс «сомнений» относительно отдельных сторон религиозных традиций. Критическое отношение «пассивных верующих» к религиозной повседневности напрямую связывается как с авторитетом мулл (имамов), их духовными и мирскими деяниями, так и с житейским 
(ценностным) содержанием проповедей мусульманских священнослужителей, значительная часть которых не имеет элементарного религиозного образования и выполняет эти обязанности из-за отсутствия более подготовленных мулл (имамов). Для некоторой части из них это духовное поприще превратилось в своеобразное занятие (промысел), которая правдами и не правдами стремится сохранить свое доходное место. Приезд на работу обученных мулл во многих деревнях воспринимается, как правило, в штыки, с одной стороны они были «чужие», не из сельского клана, с другой - вставал вопрос их финансового обеспечения. Многие приезжие священнослужители не имели средств на покупку дома или на обустройство хозяйства, к тому же значительная часть из них не была готова жить крестьянской жизнью; их потребительская психология превалировала над духовными составляющими службы.

Несмотря на наличие значительной религиозности среди населения татарских деревень, многие сельские религиозные общины или приходы (махалли) сегодня не имеют возможности на свои средства содержать мусульманские культовые и образовательные учреждения, представителей духовенства. Причина этого кроется в том, что на селе отсутствуют законодательно подкрепленные экономические составляющие и рычаги, необходимые для материально-финансового обеспечения работы мусульманских учреждений. К большому сожалению, у современных религиозных деятелей нет четкого понимания того, как и за счет каких ресурсов, внутренних или внешних, решить эту проблему. В связи с этим прогрессивно настроенное мусульманское духовенство вынуждено искать новые способы и формы укрепления своего материального положения и общественного авторитета среди селян, и стремится по мере возможностей как-то соизмерять свои интересы с духовными потребностями прихожан. Муллы (имамы) рассчитывают, в основном, на свои силы, поскольку им самим часто приходится выработать свои собственные позиции как по богословским, так и по экономическим вопросам. Однако отсутствие у мусульманских институтов и священнослужителей хорошо поставленной материально-технической базы на селе и стабильных финансовых ресурсов формирует потребительскую психологию временщика среди отдельных социальных прослоек (категорий) духовенства. Все это, в конечном итоге, загоняет духовные проблемы вглубь или отодвигает их на второй план, выпячивая вперед материально-финансовые потребности духовных лиц. В результате все это сказывается на религиозной службе и авторитете мулл (имамов), влияние которых распространяется только на религиозно-обрядовые стороны жизни сельского социума, а организация иных сторон повседневности прихожан, прежде всего, морально-нравственного плана, пускается на самотек.

Это противоречивое состояние татарского социума и мусульманского духовенства отчетливо проявляется в возникновении среди сельской молодежи различных радикальных идейно-религиозных течений, отличных от ортодоксальных канонов ислама, главной целью которых является экстремистское «зомбирование» подрастающего поколения. Показательными примером этого в каком-то смысле является религиозный фанатизм, который проявляется в увлечении молодежи средневековой мусульманской атрибутикой в плане ношения хиджабов, которые получили наибольшее распространение среди городской молодежи, чем сельской.

При этом следует заметить, что в Татарстане степень религиозности сельских жителей разных народов несколько отличается. По свидетельству отдельных исследователей [4], наибольшую активность в этом плане проявляют татары, доказательством этого является массовое строительство сельских мечетей в 1990-2000-е гг. Устойчивая религиозность среди татар объясняется тем, что ислам был тесно связан с повседневной религиозно-обрядовой жизнью села, почти каждый свадебный, родильный или поминальный обряд был привязан к мусульманскому вероучению. Мечети издревле являлись предметом гордости татар, так как они строили их на свои индивидуальные или коллективные средства, в отличие от многих православных народов России. Значимость религиозных традиций в повседневной жизни татар можно связать и с этнокультурной и гуманитарной ролью ислама, который консолидировал сельские сообщества. Особенно ярко это проявлялось в дни религиозных праздников, когда мечети наполнялись людьми разных возрастов. В это время большая часть мужского населения села собиралась в мечетях на коллективный молебен, женщины готовили праздничные кушанья. Таким образом, сегодня для основной массы верующих татар ислам является не только системой обрядов и системой формирования конфессиональной идентичности, но и важным элементом национального самосознания.

В то же время следует особо подчеркнуть, что во многих современных социологических опросах отмечается, что значительная часть жителей татарских деревень не религиозна, а суеверна, отчетливым проявлением которой является почитание «священных» мест, связанных с локальными традициями. У татар до сих пор сохранилось устное обращение к «божкам», «духам» в различные моменты хозяйственной и семейно-бытовой жизни (обращение к «святым» при неблагоприятных погодных условиях, строительстве нового дома, рождении ребенка и др.). Во время посещения «святых» родников татары читают молитвы, совершают некоторые элементы языческих культов (приносят жертвоприношения, завязывают небольшие полоски ткани на веточки деревьев (с. Билярское Алексеевского района), оставляют записки с просьбами об избавлении от болезней, о помощи в хозяйственных, семейных, любовных и других делах (Ис- 
ке-Казанское городище, вблизи с. Айша Высокогорского района) и др.). Продолжается традиция поминовения предков, у которых татары просят содействия в получении хорошего урожая, приплода скота, здоровья живущих.

Немаловажную роль в формировании этнокультурных и традиционных сторон религиозности в наши дни играют также народные календарные праздники (Сабантуй, Нардуган и др.), которые обусловлены практическими и духовными потребностями сельского татарского социума. Сегодня календарные праздники превратились в нечто новое, этноконфессиональное начало, консолидирующее мусульманское вероучение с хозяйственной жизнью села. В основе этого симбиоза лежит земледельческий труд селян, который является не только производством средств для существования, но и особым образом жизни, который в значительной степени духовно- и природообусловлен.

Таким образом, в начале XXI в. религиозность в татарском сельском социуме выступает как традиционная форма этнорелигиозного и этнонационального самосознания, активно участвует в формировании конфессиональной идентичности и социокультурного пространства. В ее основе лежит латентно развивающаяся консервативная этническая ментальность сельского обывателя и многовековая коллективная житейская психология татарского крестьянства.

\section{ЛИТЕРАТУРА}

1. Лихачев Д.С. Культура как целостная среда // Избранные труды по русской и мировой культуре. - 2-е изд., перераб. и доп. / сост. и науч. ред. А.С. Запесоцкий. - СПб.: СПбГУП, 2015. С.23.

2. Афанасьева А.Б. Этнокультурное образование: сущность, структура содержания, проблемы совершенствования // Знание. Понимание. Умение. 2009. №3. С. 189-195.

3. Набиев Р.А., Фазлиев А.М. Феномен «формальной религиозности» в контексте развития государственно-конфессиональных отношений в Республике Татарстан // Ученые записки Казанского государственного университета. Серия гуманитарные науки. 2009. Т. 151, кн. 2., ч. 2. С. 232-239.

4. Современные этнокультурные процессы в молодежной среде Татарстана: язык, религия, этничность / Я.3. Гарипов и др. - Казань: РИЦ «Школа», 2000. $138 \mathrm{c}$.

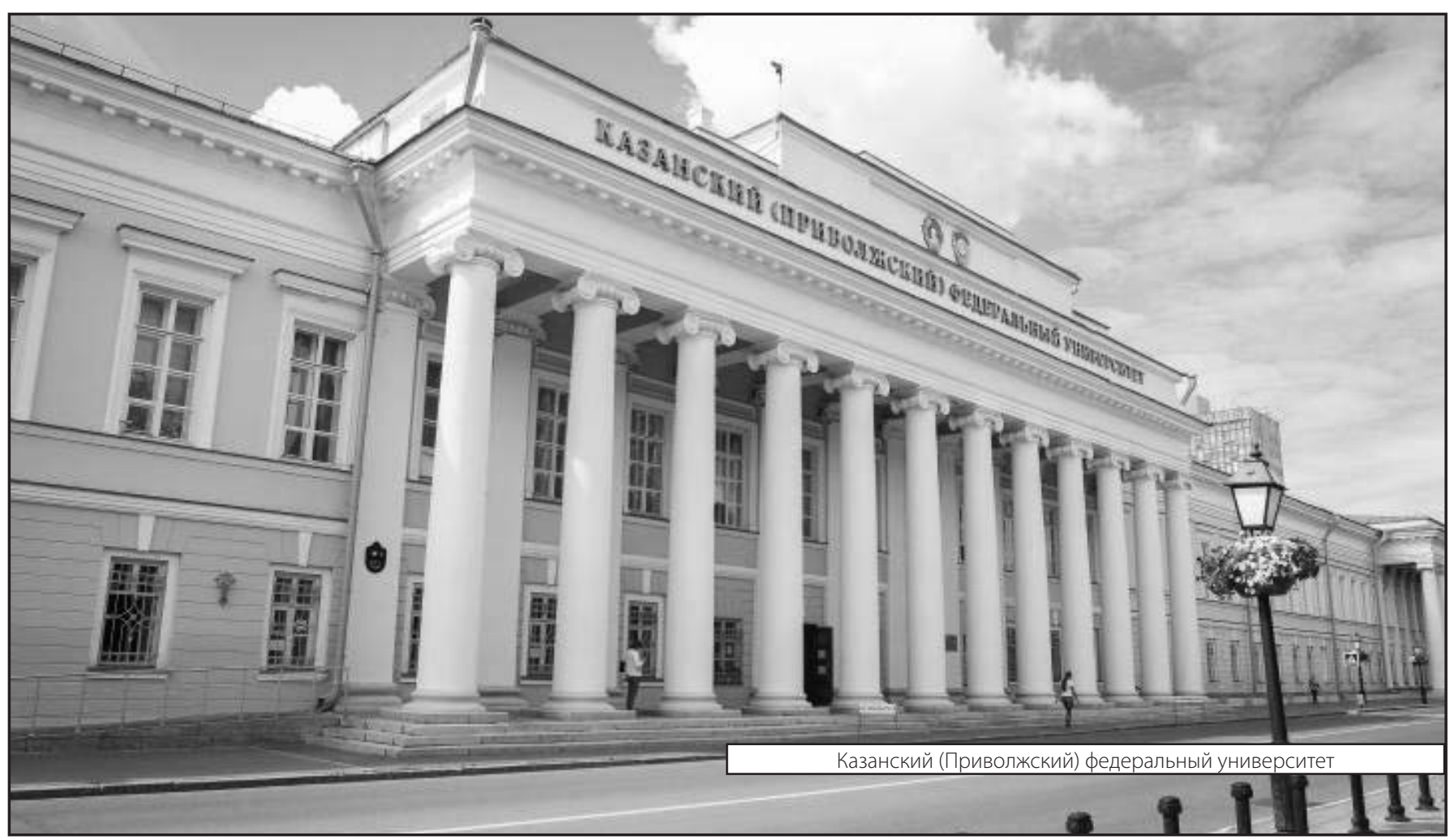

